\title{
PENGARUH MODAL, JUMLAH UNIT USAHA, NILAI INVESTASI DAN UPAH MINIMUM TERHADAP PENYERAPAN TENAGA KERJA PADA INDUSTRI KECIL DAN MENENGAH DI KABUPATEN TUBAN
}

\author{
Rosalia Agista Nur Wulansari ${ }^{1}$, Niniek Imaningsih ${ }^{2}$, Riko Setya Wijaya ${ }^{3}$ \\ ${ }^{1,2,3}$ Program Studi Ekonomi Pembangunan, Fakultas Ekonomi dan Bisnis, \\ Universitas Pembangunan Nasional "Veteran" Jawa Timur \\ rosaliaagistanurws@gmail.com
}

\begin{abstract}
Abstrak
Riset ini memiliki tujuan untuk menganalisis: 1. pengaruh Modal, Jumlah Unit Usaha, Nilai Investasi, dan Upah Minimum Kerja (UMK) terhadap penyerapan tenaga kerja pada industry kecil menegah di KabupatenTuban 2. perkembangan modal, jumlah unit usaha, nilai investasi dan upah minimum terhadap penyerapan tenaga kerja pada industri kecil dan menengah di Kabupaten Tuban .Adapun penelitian ini dilakukan di Kabupaten Tuban dan jenis data penelitian yang digunakan adalah kuantitatif dimana data diperoleh dari Dinas Koperasi Perindustrian dan Perdagangan Kabupaten Tuban. Populasi pada penelitian ini adalah industri kecil menengah di Kabupaten Tuban dan sampel yang digunakan adalah 45 industri. Riset ini menerapkan analisis regresi berganda (OLS) menggunakan program SPSS 22 for windows. Hasil Analisis menunjukkan bahwa Modal memiliki pengaruh signifikan terhadap penyerapan tenaga kerja, jumlah unit usaha mempunyai pengaruh yang signifikan terhadap penyerapan tenaga kerja, Nilai Investasi mempunyai pengaruh yang signifikan terhadap penyerapan tenaga kerja dan Upah minimum tidak menunjukkan pengaruh yang signifikan terhadap penyerapan tenaga kerja sector Industri Kecil Menengah di Kabupaten Tuban. Riset ini mempunyai tingkat keakuratan senilai 97,3\% dan sisanya2,7\% mendapatkan pengaruh dari faktor lain yang tidak penelitikaji.
\end{abstract}

Kata Kunci: Tenaga Kerja, Investasi, Unit Usaha, UMK.

\begin{abstract}
This research aims to analyze: 1. the influence of Capital, Number of Business Units, Investment Value, and Minimum Work Wage (UMK) on employment in small and medium industries in Tuban Regency 2. capital development, number of units, investment value and minimum wage on the absorption of labor in small and medium industries in Tuban Regency. This research was conducted in Tuban Regency and the type of research data used was quantitative where the data was obtained from the Department of Industry and Trade Cooperatives, Tuban Regency. The population in this study are small and medium industries in Tuban Regency and the sample used is 45 industries. This research applies multiple regression analysis (OLS) using the SPSS 22 for windows program. The results of the analysis show that capital has a significant effect on employment. Investment value has a significant effect on employment and the minimum wage does not show a significant effect on employment in the Small and Medium Industry sector in Tuban Regency. This research measures the level of accuracy of $97.3 \%$ and the remaining factor, $7 \%$ is influenced by other influences that are not detrimental.
\end{abstract}

Keywords: Labor, Investment, Business Unit, MSE 


\section{PENDAHULUAN}

Proses pembangunan sering dikaitakan dengan proses industrialisasi. Proses pembangunan industry dan proses industrialisasi sebenarnya memiliki tujuan untuk kesejahteraan masyarakat atau mengangkat derajat ekonomi keluarga. Dengan begitu pembangunan industry memiliki tujuan pokok dari berkembangnya kehidupan masyarakat yang lebih baik, tidak semata mata hanya untuk mencapai pembangunan saja. Permasalahan yang sering dihadapi adalah tingginya tingkat pengangguran, peningkatan angkatan kerja, rendahnya kualitas dari tenaga kerja, serta masih banyak lagi. Permasalahan tersebutlah yang menjadi suatu fakor yang menghambat pembangunan nasional,disebabkan hal tersebut, pemerintah seharusnya menangani permasalahan tersebut (Astiani, 2018). Didasarkan pada Undang-Undang N0.13 Tahun 2003 Tentang tenaga kerja ialah tiap individu yang bisa menjalankan pekerjaan untuk memproduksi barang ataupun jasa guna mencukupi segala keperluan pribadi ataupun masyarakat. Tenaga kerja juga bisa dikatakan sebagai penduduk yang berada pada usia kerja. Pengembangan industry dimana bersifat padat karya yang mana menjadi suatu upaya dalam memperbesar kesempatan untuk bekerja (Hajrah, 2017). Pembangunan ekonomi ialah satu kesatuan usaha kebijaksanaan yang mempunyai tujuan guna mendorong peningkatan kesejahteraan masyarakat, karena semakin meratanya kesempatan kerja dan pendapatan yang diperolehakan membuat kehidupan keluarga berkecukupan (Handayani,2016).

Pengembangan industry kecil dan menengah bisa membantu dalam penanganan permasalahan pengangguran karena saat ini jumlah penduduk menyebabkan semakin banyak masyarakat yang sulit untuk mendapatkan pekerjaan yang sesuai bidang dan kemampuan nya,karena tidak seimbangnya pertumbuhan angkatan kerja dengan penciptaan lapangan kerja dapat mengakibatkan angka pengangguran semakin tinggi.Tujuan yang ingin didapatkan dari pembangunan industry adalah mendorong penyerapan tenaga kerja dan kesempatan dalam berwirausaha, mendorong ekspor indonesia, serta mulai memberdayakan pasar didalam negeri, mendukung perkembangan sector infrastruktur, memberikan sumbangan untuk pertumbuhan ekonomi,memperkuat struktur industry, dan meningkatkan kesejahteraan rakyat dan meningkatkan penerimaan devisa (Tri, 2016) sudah memanfaatkan teknologi padatkarya yang mana mampu lebih memperluas kesempatan kerja dan kesempatan berusaha.Merujuk pada permasalahan diatas pengangguran menjadi topik yang paling sering dibahas dalam nasional maupun internasional. Fakta yang ada ialah dengan membludaknya jumlah penduduk, tetapi tidak terserap tenaga kerja.

Berikut merupakan data jumlah unit usaha dan tenaga kerja industri kecil menengah di Kabupaten Tuban:
Tabel 1.1 Jumlah Unit Usaha Dan Tenaga Kerja Industri Kecil Menengah Di Kabupaten Tuban Tahun 2017 - 2019

\begin{tabular}{|l|c|c|c|c|c|}
\hline \multirow{2}{*}{ Jenis Industri } & \multicolumn{3}{|c|}{ Jumlah unit usaha } & \multicolumn{2}{c|}{ Jumlah Tenaga K } \\
\cline { 2 - 6 } & $\mathbf{2 0 1 7}$ & $\mathbf{2 0 1 8}$ & $\mathbf{2 0 1 9}$ & $\mathbf{2 0 1 7}$ & $\mathbf{2 0 1 8}$ \\
\hline Batik & 1235 & 1255 & 1355 & 1803 & 1803 \\
\hline Kue Basah & 1243 & 1263 & 1283 & 1789 & 1798 \\
\hline Konveksi & 1322 & 1375 & 1400 & 2129 & 2155 \\
\hline Kue Kering & 651 & 670 & 196 & 1390 & 1390 \\
\hline Pengasapan Ikan & 1230 & 1245 & 1265 & 1365 & 1351 \\
\hline $\begin{array}{l}\text { Minuman Kesegaran } \\
\text { (jamu) }\end{array}$ & 543 & 640 & 792 & 1444 & 1350 \\
\hline $\begin{array}{l}\text { Jasa Reparasi } \\
\text { Mesin }\end{array}$ & 869 & 900 & 927 & 1865 & 1800 \\
\hline Bengkel Las & 734 & 745 & 861 & 2345 & 2200 \\
\hline Penggilingan & 923 & 943 & 1002 & 1886 & 1857 \\
\hline Kerupuk/Keripik & 1292 & 1310 & 1342 & 3300 & 3120 \\
\hline Kerajinan Bambu & 1178 & 1201 & 1285 & 2754 & 2345 \\
\hline Meubel/Furniture & 987 & 993 & 1028 & 3000 & 3029 \\
\hline Gerabah & 1335 & 1337 & 1411 & 3300 & 3419 \\
\hline Batu Bata & 1234 & 1268 & 1345 & 2315 & 2400 \\
\hline Pengolahan Daging & 1329 & 1378 & 1410 & 2768 & 2983 \\
\hline TOTAL & $\mathbf{1 6 1 0 5}$ & $\mathbf{1 6 5 2 3}$ & $\mathbf{1 6 9 0 2}$ & $\mathbf{3 3 4 5 3}$ & $\mathbf{3 3 0 0 0}$ \\
\hline
\end{tabular}

Sumber: Dinas Koperasi Perindustrian Dan Perdagangan Kab Tuban 2017-2019 (Data Diolah).

Table 1.1 memperlihatkan jumlah industry kecil dan menengah dan juga jumlah tenaga kerja pada industry kecil dan menengah tersebut. Dalam table 1 tampak bahwa terjadinya fluktuasi pada jumlah industry kecil dan menengah. Terlihat bahwa dari tahun 2017 sampai 2019 meningkat,

Dari tahun 2017 total ikm 16.105 unit usaha. Pada tahun 2018 sebesar 16.523 unit usaha dan pada tahun 2019 sebesar 16.902 unit usaha. Sesuai dengan perkembangan dalam industry kecil dan menengah di Kabupaten Tuban pasti mempunyai berbagai macam kendala yang mana mengakibatkan tenaga kerja yang terserap belum lah optimal, antara lain yaitu keterbatasan modal, sulitnya perkembangan pada unit usaha dikarenakan mengingat banyak pesaing yang memiliki usaha yang sama, kurangnya inovasi dan kreatifitas terhadap produk yang dimiliki sehingga membuat produk yang kita miliki kalah bersaing dengan produk baru atau unit usaha baru. Penelitian ini bertujuan guna mendapatkan informasi terkait pengaruh modal terhadap penyerapan tenaga kerja pada industry kecil menengah diKabupaten Tuban, guna mendapatkan informasi terkait pengaruh jumlah unit usaha terhadap penyerapan tenaga kerja pada industri kecil menengah di Kabupaten Tuban, guna mendapatkan informasi terkait pengaruh nilai investasi terhadap penyerapan tenaga kerja di kabupaten Tuban, guna memperoleh informasi terkait pengaruh upah minimum terhadap penyerapan tenaga kerja di Kabupaten Tuban 


\section{KAJIAN PUSTAKA}

\section{Industri}

Pada Undang Undang Republik Indonesia No. 3 Tahun 2004 tentang perindustrian menyebutkan bahwa industry merupakan segala hal yang berwujud aktivitas ekonomi dalam mengolah bahan baku atau mendayagunakan sumber daya yang terdapat di dalam industri tersebut yang tujuannya untuk menciptakan sebuah produk bernilai tambah atau lebih bermanfaat, termasuk jasa industry. Peran sektor industry menurut (Hasanah, 2016). Industry merupakan kegitan ekonomi yang menghasilkan nilai tambah. Secara ekonomi makro nilai tambah tidak hanya digunakan untuk menunjang peningkatan PDB melainkan juga dapat meningkatkan kesejahteraan masyarakat (Prabaningtyas, 2015)

\section{Tenaga kerja}

Sumber daya manusia (SDM) atau Human Resourcesyang memiliki dua definisi, yakni pertama, suatu usaha ataupun jasa yang ditunjukkan pada proses produksi. Pengertian ini mengartikan bahwa SDM merupakan sebuah mutu dari pekerja dalam periode tertentu guna memproduksi barang ataupun jasa. Definisi kedua dari SDM ialah individu yang memiliki kemampuan dalam melangsungkan kerja sehingga dapat menghasilkan jasa ataupun upaya dalam menunaikan pekerjaan yang dimilikinya. Kesanggupan kerja diartikan sebagai kesanggupan untuk menjalankan aktivitas yang bernilai ekonomis, yakni aktivitas memproduksi barang ataupun jasa yang kegunaannya untuk mencukupi kebutuhan dari masyarakat. Kemampuan bekerja dilihat dari usia. Melalui arti individu yang berada pada usia kerja yang sanggup bekerja. Sekelompok penduduk yang berada pada usia kerja disebut tenaga kerja atau Man Power (Muhammad, 2014). Di dalam('Undang Undang No 13', )Tahun 2003 Tentang Ketenagakerjaan, tenaga kerja didefinisikan sebagai individu yang memiliki kemampuan dalam bekerja untuk memproduksi barang ataupun jasa dalam kualitas yang baik sehingga dapat mencukupi kebutuhan pribadi sekaligus masyarakat.Tenaga kerja adalah penduduk yang berada pada usia kerja (15-64 tahun) atau total penduduk dimana dapat bekerja serta menghasilkan barang dan jasa jika mereka menerima permintaan untuk memerikan tenaga yang mereka miliki dan turut andil atas aktivitas yang dilangsungkan tersebut.

\section{Kesempatan Kerja}

Merupakan akumulasi individu yang bisa masuk kedalam suatu perusahaan untuk melakukan suatu pekerjaan, dan didalam suatu instansi atau perusahaan yang dimaksudkan dapat menerima seluruh tenaga kerja yang tengah tersedia jika lapangan pekerjaannya mencukupi untuk memberikan pekerjaan terhadap tenaga kerja tersebut. Meningkatnya laju dari pertumbuhan penduduk dan angkatan kerja dapat diperkirakan permasalahan di dalam kesempatan kerja akan timbul, dalam hal ini kesempatan kerja berkaitan dengan sejumlah aspek baik di dalam sektor ekonomi ataupun yang bukan ekonomi, terlebih itu upaya untuk memperbesar peluang masyarakat untuk memperoleh pekerjaan merupakan sebuah upaya untuk mendorong peningkatan taraf hidup. (Handayani, 2016). Badan Pusat Statistik dalam(Hajrah, 2017) mendefinisikan bahwa kesempatan kerja ialah akumuasi total dari individu yang berada pada satu wadah atau yang disebut dengan perusahaan untuk bekerja. Kesempatan untuk memperoleh pekerjaan inilah yang akan menjadi wadah para tenaga kerja yang saat ini tersedia, jikala pangan pekerjaan yang ada saat ini berada pada kondisi seimbang dengan akumulasi dari tenaga kerja saat ini.Secara umum kesempatan kerja dapat diartikan sebagai tersedianya upaya produksi untuk memberikan sebuah pekerjaan kepada tenaga kerja yang akan terlibat dalam proses produksi, dimana bisa diartikan bahwalapangan pekerjaan ataupun peluang yang saat ini ada guna memperoleh pekerjaan di dalam sebuah aktivitas ekonomi (produksi), di dalamnya berisikan seluruh lapangan pekerjaan yang tersedia. Pengukuran akan kesempatan kerja ini ditinjau berdasarkan akumulasi individu yang memperoleh pekerjaan dalam periode tertentu yangdilihat berdasarkan aktivitasekonomi.

Penyerapan tenaga kerja diartikan sebagai akumulasi tertentu yang berasal dari tenaga kerja yang bekerja pada sebuah unit usaha atau dapat diartikan sebagai tenaga kerja yang berhasil terserap pada sebuah unit usaha. Ketika menyerap tenaga kerja, maka akan memperoleh pengaruh dari dua faktor, yakni eksternal dan internal.(Prabaningtyas, 2015)

Berdasarkan ('Undang Undang No 13',)Tahun 2003 Tentang Ketenagakerjaan, tenaga kerja ialah tiap individu yang dapat menjalankan pekerjaan untuk menciptakan barang atau jasa baik sehingga dapat memenuhi keperluan pribadi ataupun masyarakat. Tenaga kerja ialah penduduk yang berada pada usiakerja (15-64 tahun) atau jumlah semua penduduk yang dapat bekerja serta menciptakan barang dan jasa jika mereka mendapatkan permintaan terhadap tenaga mereka dan mereka dapat ikut serta pada kegiatan tersebut.

\section{Modal}

Modal dinilai sebagai penyerapan tenaga kerja. Besarnya modal yang di investasikan tentunya dapat meningkatkan permintaan tenaga kerja atau peningkatan terjadi dengan asumsi factor factor produksi yang lain konstan didalam usaha modal adalah hal penting yang dibutuhkan. Modal ialah seluruh wujud dari kekayaan dimana dipergunakan baik secara langsung atau tidak 
langsung pada proses produksi guna meningkatkan output. Modal ialah sumber ekonomi selain tenaga kerja dimana hasil rekayasa yang dilakukan oleh manusia. Terkadang modal dinilai ke dalam bentuk uang atau keseluruhan nilai dari sumber ekonomi non manusiawi. Hal inilah yang menyebabkan apabila merujuk pada modal dalam artian yang lebih luas, maka disebutkan seluruh sumber ekonomi selain tenaga kerja (Fadilah, 2012)

\section{Jumlah Unit Usaha}

Badan Pusat Statistik mengartikan unitusaha ialah unit yang menjalankan aktivitasdimana dilaksanakan oleh seseorang atau rumah tangga ataupun sebuah badan serta memiliki kewenangan yang penentuannya didasarkan pada lokasi bangunan fisik serta wilayah operasionalnya.Umumnya pertumbuhan unit usaha disebuah wilayah dapat memperbanyak lapangan pekerjaan ,dapat diartikan bahwa terjadinya peningkatan dalam permintaan tenaga kerja. ('Badan Pusat Statistik Kabupaten Tuban'Tentang Perindustrian) dengan banyaknya perusahaan ataupun unit usaha dalam sebuah daerah yang mana tentunya membutuhkan tenaga kerja yang banyakpula (Widyastuti, 2013).

\section{Nilai Investasi}

Investasi ialah dana yang diluarkan untuk memeperbanyak ataupun menjagapersediaan modal atau Capital Stock. Persediaan tersebut antara lain peralatan, berbagai jenis mesin, pabrik dan persediaan bahan baku dimana dapat dipergunakan ketika proses produksi. Sehingga investasi ialah pengeluaran dimana ditujukan guna memperbanyak modal. Pada neraca nasional atau struktur Produk Domestik Bruto (PDB) berdasarkan pemanfaatannya investasi dapat diartikan sebagai suatu hal yang menentukan laju pertumbuhan ekonomi, dikarenakan selain dapat meningkatkan output secara signifikan dan otomatis dapat mendorong peningkatan permintaan input, yang mana mengakibatkan pada saatnya dapat mendorong peningkatan peluang kerja dan kesejahteraan masyarakat sebagai suatu dampak dari peningkatan pendapatan yang didapatkan masyarakat (Jaunita, 2016).

Menurut (Gunawan, 2018)investasi ialah pengeluaran atau penanaman modal atau perusahaaan guna membelanjakan nya ke berbagai barang modal beserta perlengkapan produksi guna meningkatkan kemampuan produksi barang dan jasa yang tersedia pada perekonomian. Penambahan jumlah modal dapat memperlihatkan pengaruh terhadap perekonomian dikarenakan dapat menghasilkan barang dan jasa lebih banyak dikemudian hari. Penanaman modal bisa dikelompokkan ke dalam menjadi penanaman modal Badan Usaha Milik Negara, penanaman swasta dan penanaman modal pemerintahumum.

\section{Upah Minimum}

Berdasarkan('Keputusan Menteri No.1', 1999) Pasal 1 ayat 1 , tentang upah minimum ialah upah bulanan paling rendah dimana tersusun atas upah pokok tidak terkecuali dengan tunjangan tetap. Dimana maksud dari kata tunjangan tetap ialah jumlah imbalan yang diberikan kepada pekerja secara tetap dimana dibayarkan secara teratur serta tidak disangkut pautkan dengan kehadiranmaupun pencapaian prestasi tertentu. Tujuan dari ditetapkannya upah minimum ialah guna memperoleh penghasilan yang layak bagi pekerja. Sejumlah hal yang dipertimbangkan dalam hal ini, tidak terkecuali dalam upaya peningkatan kesejahteraan para pekerjatanpa menafikan produktifitas perusahaan dan kemajuannya tidak terkecuali dalam mepertimbangkan kondisi ekonomi secara umum. Payaman J Simanjutak dalam(Nurafuah, 2015)berdasarkan teori klasik mengidentifikasikan upah sebagai upaya untuk mendongkrakkan keuntungan yang akan dimiliki setiap perusahaan dengan memanfaatkan sejumlah faktor di dalam produksi sehingga setiap faktor di dalam produksi yang dimanfaatkan akan mendapatkan ataupun memberi imbalan yang sesuai dengan nilai penambahan hasil marginal yang diperoleh dari factor produksi tersebut atau dapat diartikan bahwa tenaga kerja diberikan upah yang sesuai dengan pertumbuhan hasil marginalnya

\section{METODE PENELITIAN}

Metode kuantitatif ialah metode yang digunakan dalam melangsungkan penelitian yang dimana menegakkan asas positivisme, penggunaan metode ini ditujukan untuk melangsungkan penelitian terhadai suatu populasi dan sampel yang telah ditentukan sehingga dapat memperoleh angka yang akan digunakan untuk menguji hipotesis yang sudah diterapkan. (Safitri, 2017)data diperoleh dari Dinas Koperasi Perindustrian dan Perdagangan di Kabupaten Tuban. Lokasi wilayah yang digunakan pada penelitian ini dilakukan di wilayah Kabupaten Tuban khususnya pada industri kecil dan menengah. Data yang dipakai guna mewujudkan tujuanpada riset ini secara keseluruhan dengan data sekunder. Data yang didapatkan ialah sekumpulan data dari catatan tertulis Diskoperindag Kabupaten Tuban. Pada riset ini menggunakan pendekatan metode kuantitatif dengan analisis regresi linier berganda. Dan sampel penelitian yang dipergunakan ialah 15 industri kecil menengah dengan pengamatan dari tahun 2017 - 2019, dengan begitu terdapat 45 industri kecil menengah yang digunakan sebagai sampel. Metode analisis regresi linier:

$$
\begin{aligned}
& \mathrm{Y}=\beta 0+\beta 1 \mathrm{X} 1+\beta 2 \mathrm{X} 2+\beta 3 \mathrm{X} 3+\beta 4 \mathrm{X} 4+\ldots+ \\
& \beta \mathrm{nxn} \\
& +\mathrm{e}
\end{aligned}
$$


Keterangan :

Y : Variabel Dependen

B0: Dugaan Bagi Parameter Konstanta B1, B2, B3,

B4,

ßn: Dugaan Bagi Parameter ß1, ß2, ß3, ß4, ßn

$\mathrm{X} 1, \mathrm{X} 2, \mathrm{X} 3, \mathrm{X} 4, \mathrm{Xn}$ :Variabel Independen

e : sisa (eror)

Dari bentuk umum model regresi linier berganda tersebut bisa diperkirakan denganmodel regresi linier berganda untuk sampel, yakni seperti di bawah ini :

$\mathrm{Y}=\beta 0+\beta 1 \mathrm{X} 1+\beta 2 \mathrm{X} 2+\beta 3 \mathrm{X} 3+\beta 4 \mathrm{X} 4+\mathrm{e}$

Keterangan:

Y : Penyerapan Tenaga Kerja

X1 : Modal

X2 : Jumlah Unit Usaha

X3 : Nilai Investasi

X4 : UpahMinimum $30 \quad$ :Konstanta

ß1, ß2, ß3, ß4 :Koefisien Regresi

e : Variabel Pengganggu atau standart eror

\section{HASIL DAN PEMBAHASAN}

\section{Uji Normalitas}

Gambar 4.1 Hasil Uji Normalitas One Sample Kolmogoriv Smirnov

$\begin{aligned} & \text { One-Sample } \\
& \text { Test }\end{aligned}$
\begin{tabular}{|ll|l|}
\hline & & $\begin{array}{l}\text { Unstanda } \\
\text { rdized } \\
\text { Residual }\end{array}$ \\
\hline $\mathrm{N}$ & & 45 \\
Normal & Mean &, 0000000 \\
Parameters $^{\mathrm{a}, \mathrm{b}}$ & Std. & 159,6330 \\
& Deviation & 1085 \\
Most Extreme & Absolute &, 101 \\
Differences & Positive &, 101 \\
& Negative &,- 061 \\
Test Statistic & &, 101 \\
Asymp. Sig. (2-tailed) & &, $200^{\mathrm{c}, \mathrm{d}}$ \\
\hline
\end{tabular}

a. Test distribution isNormal.

b. Calculated fromdata. c. Lilliefors SignificanceCorrection.

d. This is a lower bound of the true significance.

Sumber: Output SPSS 22.0 (Data Diolah) 
Berdasasrkan output uji spss sebelumnya memperlihatkan bahwa nilai signifikan Asiymp.Sig (2-tailed) senilai 0,200 melebihi dari 0,05 . Sehingga sejalan dengan dasar pengambilan keputusan pada uji normalitas Kolmogorov smirnov sebelumnya, bisa ditariksimpulan bahwa data memperlihatkan distribusi normal. Sehingga, asumsi atau persyaratan normalitas pada model regresi telah terpenuhi.

\section{Uji Multikolinearitas}

\section{Tabel 4.1 HasilUjiMultikolinearitas} Coefficients $^{\mathrm{a}}$

\begin{tabular}{|c|c|c|}
\hline \multirow[b]{2}{*}{ Model } & \multicolumn{2}{|c|}{$\begin{array}{c}\text { Collinearity } \\
\text { Statistics }\end{array}$} \\
\hline & $\begin{array}{c}\text { Tolera } \\
\text { nce }\end{array}$ & VIF \\
\hline $\begin{array}{ll}1 & \text { (Const } \\
\text { ant) }\end{array}$ & & \\
\hline $\mathrm{MDL}$ & 390 & 2,561 \\
\hline $\mathrm{JU}$ & 969 & 1,032 \\
\hline NI & 375 & 2,663 \\
\hline UP & ,938 & 1,067 \\
\hline
\end{tabular}

Didasarkan tabel diatas sehingga bisa diperoleh informasi untuk nilai tiap variabel modal, jumlah unit usaha, nilai investasi dan upah minimum mempunyai nilai tolerance melebihi 0,10 dan VIF di bawah 10. Dan untuk nilai VIF setiap variabel adalah variabel modal sebesar 2,561, variabel jumlah unit usaha sebesar 1,032, variabel nilai investasi sebesar 2,663 dan untuk nilai VIF variabel upah minimum sebesar 1,067. Sehingga bisa ditarik simpulan bahwadidasarkan pada nilai tolerance dan nilai VIF dari tiap variabel sehingga model regresi ini terbebas dari gejala multikolinearitas atau layak digunakan dalam pengujian.

\section{Uji Heterokedastisitas}

\section{Gambar \\ 4.2 Hasil Uji Heterokedastisitas}

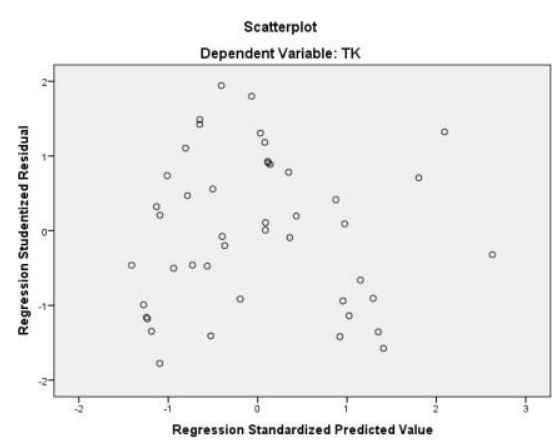

Sumber: Output SPSS 22.O (Data Diolah). Berdasarakan dari grafik scaterplot tersebut, tampak bahwa sejumlah titik yang letaknya tersebar dan mengacak serta tidak membentuk suatu pola yang jelas, dan juga penyebarannya baik diatas ataupun dibawah angka 0 pada sumbu y yang mana bisa diartikan bahwa heterokedastisitas tidaklah terjadi dalam model regresi, maka model regresi layak digunakan.

\section{UjiAutokorelasi}

Tabel 4.2 Hasil Uji Autokorelasi

Model Summary
\begin{tabular}{|l|c|r|r|r|r|}
\hline $\begin{array}{l}\text { Mod } \\
\mathrm{el}\end{array}$ & $\mathrm{R}$ & $\begin{array}{c}\mathrm{R} \\
\text { Square }\end{array}$ & $\begin{array}{c}\text { Adjusted } \\
\text { R Square }\end{array}$ & $\begin{array}{c}\text { Std. Error } \\
\text { of the } \\
\text { Estimate }\end{array}$ & $\begin{array}{c}\text { Durbin- } \\
\text { Watson }\end{array}$ \\
\hline 1 &, $973^{\mathrm{a}}$ &, 946 &, 941 & 167,42451 & 2,1211 \\
\hline
\end{tabular}
a. Predictors: (Constant), UP, JU, MDL, INI
b. Dependent Variable: TK

Sumber : Output SPSS 22.O (Data Diolah)

a. Apabila nilaiDwkurang dari -2 dapat diartikanbahwaTerdapatautokorelasipo sitif

b. Apabila nilai DW diantara -2hingga +2 dapat diartikan

c. bahwa tidak ditemukannya autokorelasi

d. Apabila nilai DW melebihi +2 makadiartikanditemukannya autokorelasinegative.

Berdasarkan hasil uji autokorelasi diatas maka diartikan bahwa tidak terjadi gejala autokorelasi, karena dl : 1,2874, du : 1,7762

, 4-du : $4-1,7762=2,2238$

Dapat diartikan( du< d < 4-du ) : $1,7762<$ $2,1211<2,2238$. Autokorelasi tidaklah terjadi.

\section{Analisis Regresi Linier Berganda}

Tabel 4.3 Hasil UjiRegresi

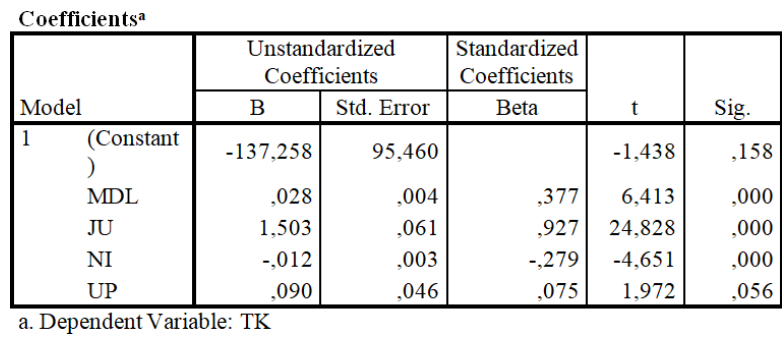

\section{regresi linierbergandadalamtabel4.3 adalahseperti di bawah ini:}

1. Nilai koefisien regresi modal senilai 0,028 dimana dapat diartikan bahwa tiap peningkatan atau penurunan modal senilai Rp. 1 (rupiah)sehingga dapat disesuaikan dengan penurunan ataupun peningkatan penyerapan tenaga kerja senilai 0,028 jiwa.

2. Nilai koefisien regresi jumlah unit 
usaha senilai 1,503 dapat diartikan bahwa tiappeningkatanatau penurunan jumlah unit usaha 1 unitsehingga dapat disesuaikan dengan penurunan ataupun peningkatan penyerapan tenaga kerja senilai 1,503 jiwa.

3. Nilai koefisien regresi nilai investasi senilai -0,012 dimana dapat diartikan bahwa tiap peningkatan atau penurunan nilai investasi senilai Rp 1 (rupiah) dapat diikuti dengan penuruan ataupun peningkatan penyerapan tenaga kerja senilai - 0,012jiwa.

4. Nilai koefisien regresi upah minimum senilai 0,090 dimana dapat diartikan bahwa tiap peningkatan ataupun penurunan upah minimum senilai Rp 1 (rupiah) sehingga bisa disesuaikan dengan penurunan ataupun peningkatan penyerapan tenaga kerja senilai 0,090jiwa.

Uji T

Tabel 4.4 Hasil Regresi Uji t

\begin{tabular}{|c|c|c|c|c|c|c|}
\hline \multicolumn{7}{|c|}{ Coefficients $^{\mathrm{a}}$} \\
\hline \multirow{2}{*}{\multicolumn{2}{|c|}{ Model }} & \multicolumn{2}{|c|}{$\begin{array}{c}\text { Unstandardized } \\
\text { Coefficients }\end{array}$} & \multirow{2}{*}{$\begin{array}{c}\begin{array}{c}\text { Standardized } \\
\text { Coefficients }\end{array} \\
\text { Beta }\end{array}$} & \multirow[b]{2}{*}{$t$} & \multirow[b]{2}{*}{ Sig. } \\
\hline & & $B$ & Std. Error & & & \\
\hline \multirow[t]{5}{*}{1} & (Constant) & $-137,258$ & 95,460 & & $-1,438$ &, 158 \\
\hline & $\mathrm{MDL}$ & 028 &, 004 &, 377 & 6,413 &, 000 \\
\hline & $\mathrm{JU}$ & 1,503 & 061 &, 927 & 24,828 &, 000 \\
\hline & INI &,- 012 &, 003 &,- 279 & $-4,651$ &, 000 \\
\hline & UP &, 090 &, 046 &, 075 & 1,972 &, 056 \\
\hline
\end{tabular}

Sumber: Output SPSS 22.0 (Data Diolah). Didasarkan paa hasil regresi linier berganda didapati hasil di bawah ini:

1. Variabel modal (X1) mempunyai nilai signifikan sebesar 0,000 yang berarti nilai signifikan kurang dari levelofsignificance $(0,05)$.Sehingga variabel modal memiliki pengaruh signifikan terhadap penyerapan tenagakerja.

2. Variabel jumlah unit usahamempunyai nilai signifikan senilai 0,000 yang dapat diartikan nilai signifikan kurang dari level of significance ( 0,05). Sehingga variabel jumlah unit usaha memiliki pengaruh signifikan terhadap penyerapan tenagakerja.

3. Variabel nilai investasi mempunyai nilai signifikan senilai 0,000 yang berarti nilai signifikan kurang dari levelofsignificance $(0,05)$.Sehingga variabel nilai investasi memiliki pengaruh signifikan terhadap penyerapan tenagakerja.

f. Variabel upah minimum tidak memiliki pengaruh signifikan senilai 0,056 dimana dapat diartikan tidak signifikan dengan level of significance ( 0,05). Jadi variabel upah minimum tidak memiliki pengaruh signifikan terhadap penyerapan tenagakerja.

Uji f

Tabel 4.5 Hasil Uji F

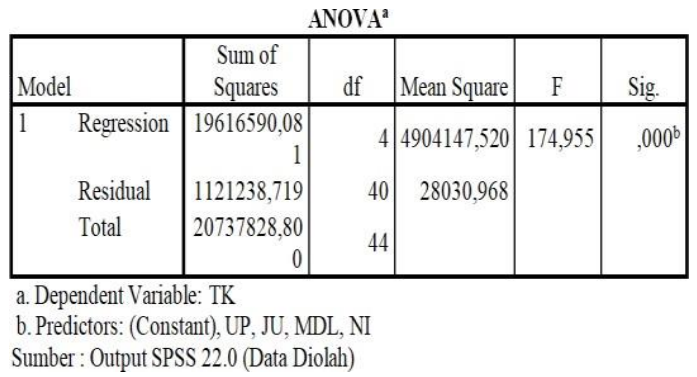

Berdasarkan hasil regresi didapatkan $\mathrm{F}$ senilai 174,955 dengan signifikasi senilai 0,000 dapat diartikan bahwa analisis ini signifikan dengan tingkat signifikasi di bawah 5\% sehingga menolak H0 serta menerima Ha. Sehingga dapat dinilai bahwa secara simultan variabel modal, jumlah unit usaha, nilai investasi dan upah minimum memberikan pengaruh kepada penyerapan tenaga kerja.

\section{Uji Koefisien Determinasi}

Tabel 4.6 Hasil RegresiKoefisien Determinasi (R Square)

Model Summary ${ }^{\mathrm{b}}$

\begin{tabular}{|l|l|r|r|}
\hline $\begin{array}{l}\text { Mod } \\
\text { el }\end{array}$ & R & $\begin{array}{c}\text { R } \\
\text { Square }\end{array}$ & $\begin{array}{c}\text { Adjusted R } \\
\text { Square }\end{array}$ \\
\hline 1 &, $973^{\mathrm{a}}$ &, 946 &, 941 \\
\hline
\end{tabular}

a. Predictors: (Constant), UP, JU, MDL, NI

b. Dependent Variable: TK

Sumber: Output SPSS 22.0 (Data Diolah) Berdasarkan hasil rgresi tersebut terlihat bahwa nilai koefisien adalah 94,6\% atau 0,946 yang menunjukkan bahwa $94,6 \%$ variable penyerapan tenega kerja bisa dipaparkan oleh variabel modal, jumlah unit usaha, nilai investasi dan upah minimum. Akan tetapi untuk sisanya yakni senilai 5,4\% dipaparkan oleh variable lainnya diluar penelitian ini.

\section{Pembahasan}

Hubungan Modal Terhadap Penyerapan Tenaga Kerja

Penelitian ini memperoleh hasil serupa dengan penelitian dari Sri Handayani dalam 
penelitian (PRATAMA, 2016)mengatakan bahwa modal dapat dialokasikan untuk membeli mesin dan menunjang produktivitas. Sehingga mesin beserta peralatan yang digunakan di dalam proses produksi dapat memberikan pengaruh terhadap tenaga kerja yang mampu terserap, dikarenakan mesin beserta peralatan produksi dapat mengambil peran tenaga kerja. Sehingga peningkatan modal yang dialokasikan untuk membeli mesin akan mengakibatkan tenaga kerja yang dapat diserap mengalami penurunan. Pengalokasian modal untuk membeli mesin akan menunjang produktivitas.

\section{Hubungan Jumlah Unit Usaha Dengan Penyerapan TenagaKerja}

Hasil penelitian didukung dengan Tri Wahyu Rejekiningsih didalam penelitian (Muhammad, 2014)bahwa penyerapan tenaga kerja memiliki pengaruh positif. Karena peningkatan jumlah unit usaha akan mendorong penyerapan tenaga kerja, dan sebaliknya. Meningkatnya jumlah perusahaan akan mengakibatkan meningkatnya jumlah output yang dapat diperoleh yang tentunya memperbesar kesempatan kerja dan menekan angka pengangguran yang dimana diindikasikan bahwa penyerapan tenaga kerja mengalami peningkatan.

\section{Hubungan Nilai Investasi Dengan Penyerapan TenagaKerja}

Penelitian ini memperoleh hasil yang didukung oleh (Hasanah, 2016)menyatakan bahwa investasi yang dilaksanakan pada perusahaan akan memiliki pengaruh pada kesempatan kerja. Hal ini dapat terjadi karena proses dalam produksi dapat meningkat dan untukmenjalankan proses produksi memerlukan tenaga kerja manusia sehingga perusahaan akan menambah tenaga kerja. Investasi ialah biaya yang harus dikeluarkan untuk membeli sejumlah barang modal dan peralatan produksi dengan tujuan untuk mengganti ataupun memperbanyak barang modal dalam perekonomian yang nantinya akan difungsikan untuk memproduksi barang dan jasa di kemudian hari.Investasi yang dilakukan pada perusahaan akan memiliki pengaruh pada kesempatan kerja.Investasi memiliki dampak pengganda terhadap output.

\section{Hubungan Upah Minimum Dengan Penyerapan TeanagKerja}

Upah tenaga kerja termasuk ke dalam biaya produksi, dimana peningkatan upah ini akan menekan laba yang akan diperoleh perusahaan untuk mengoptimalkan laba ini dapat dilakukan melalui menekan biaya serta menunjang input produksi sehingga lebih mendatangkan keuntungan secara lebih optimal. (Sukarsono, 2019)menyatakan bahwa upah tidak memiliki pengaruh terhadap permintaan tenaga kerja. Hal ini berarti bahwa setiap kenaikan upah minimum mengakibatkan pengurangan penyerapan tenaga kerja. karena semakin tingginya upah minimum kerja yang ditetapkan maka pengusaha akan mencari alternatif lain dengan menggunakan industrialisasi atau denganmasinal.

\section{KESIMPULAN}

Variabel modal memilikipengaruh dan signifikan terhadap penyerapan tenaga kerja.Hasil dari koefisien regresi senilai 0.000 kurang dari nilai signifikasi 0,05,yang mana biasdiartikan apabila penanaman modal semakin meningkat, maka akan menyebabkanpenambahan penggunaan tenaga kerja atau bisa dikatakan bahwa terjadinya peningkatan dalam menyerap tenaga kerja karena apabila modal yang ditanamkan dalam suatu unit usaha atau perusahaan semakin banyakatau semakin tinggi sehingga pengusaha akan menambahkan tenaga kerja untuk membantu dalam proses produksinya.

Variabel jumlah unit usaha memiliki pengaruh dan signifikan terhadap penyerapan tenaga kerja. Hasil dari koefisien regresi senilai0,000 kurang dari nilai signifikasi 0.05.yang mana bisa diuraikan bahwa apabila jumlah unit usaha semakin banyak sehingga dapat menambah penggunaan tenaga kerja. Karena jika jumlah unit usaha terus berkembang tentunya dapat mempersempit atau akan semakin menurunkan jumlah pengangguran dan dalam proses produksi dengan jumlah unit usaha yang semakin meningkattidakakanmungkinproses produksi dilakukan oleh satu orang saja,sehingga semakin besar jumlah unit usaha akan memberikan peluang untun tenaga kerja bekerja pada unit usahatersebut.

Variabel nilai investasi terhdap penyerapan tenaga kerja memiliki pengaruh dan signifikan terhadap penyerapan tenaga kerja. Hasil dari koefisien regresi senilai 0,000 kurangdari nilai signifikasi 0,05 ,yang diartikan apabila investasi dimana diterapkanuntuk menyediakan sejumlah barang modal contohnya mesin beserta perlengkapan produksi guna mendorong peningkatanhasiloutput dapat mendorong peningkatan dalam menyerap tenaga kerja dikarenakan barang modal tersebut memerlukan tenaga manusia dalam mengoperasikan mesin tersebut. Karena besarnya investasi yang dijalankan dapat memperbanyak penyerapan tenaga kerja khususnya investasi yang memiliki sifat padat karya.Variabel upah minimum tidaklah menunjukkan pengaruh yang signifikan terhadap penyerapan tenaga kerja. Hasil koefisien regresi senilai0,056 melebihi nilai signifikan 0,05. Yang mana bisa diartikan bahwa kenaikan tingkat upah dapat menyebabkan penurunan tenagakerja olehpengusaha.

\section{DAFTAR PUSTAKA}

Astiani, D. (2018). 'Pengaruh Tingkat Upah, Modal, Lama Usaha Dan Pendapatan 
Terhadap Penyerapan Tenaga Kerja Pada Industri Gerabah Dikabupaten Bantul', Universitas Islam Indonesia Fakultas Ekonomi Yogyakarta.

('Badan Pusat Statistik Kabupaten Tuban Tentang Industri', )

Fadilah, D. N. (2012). 'ANALISIS PENYERAPAN TENAGA KERJA PADA INDUSTRI KECIL', UNIVERSITAS DIPONEGORO SEMARANG FAKULTAS EKONOMI DAN BISNIS.

Gunawan, M. D. (2018). 'Analisis Pengaruh Jumlah Unit Usaha, Investasi Dan Upah Minimum Terhadap Penyerapan Tenaga Kerja Pada Sektor Industri Pengolahan Besar dan Sedang Di Kota Surabaya', Universitas 17 Agustus 1945 Surabaya Fakultas Ek.

Hajrah, H. (2017). 'Pengaruh NilaiProduksi, Investasi Dan Jumlah Unit Usaha Terhadap Penyerapan Tenaga Kerja Pada Sektor Industri Kecil Dan Menegah Di Kota Makasar', Universitas Islam Negeri Alauddin Makasar Jurusan Ilmu Ekonomi Fakultas Ekonomi Bisnis.

Handayani, R. (2016). 'Pengaruh Jumlah Unit Usaha Dan Upah Minimun Regional Terhadap Penyerapan Tenaga Kerja Pada Industri Kecil dan Menegah DiKabupaten Bantaeng tahun 2001-2015', Universitas Islam Negeri Alauddin Makasar Fakultas Ekonomi Dan Bisnis Islam.

Hasanah, F. U. (2016). 'Analisis Penyerapan Tenaga Kerja Pada Industri Menengah dan Besar SeKaresidenan Pekalongan Tahun 2008-2013. UniversitasMuhammadiyah Surakata.', Universitas Muhammaddiyah Surakarta Jurusan Ekonomi Pembangunan Fakultas Ekonomi dan Bis.

Jaunita, T. (2016). 'Analisis Data Panel Pengaruh UMR, Nilai Output, Jumlah Unit Usaha Dan Investasi Terhadap Penyerapan Tenaga Kerja Pada Sektor Industri Besar Dan Sedang Di Jawa Tengah', Universitas Muhammadiyah Surakarta Jurusan Ekonomi Pembangunan Faku.

('Keputusan Menteri No.1 1999 Pasal 1 Ayat 1 Tentang Upah Minimum', )

Muhammad, A. (2014). 'Analisis Penyerapan Tenaga Kerja Pada Industri Kecil Dan Menengah Di Provinsi Jawa Tengah', Universitas Diponegoro Semarang Fakultas Ekonomika dan Bisnis.

Nurafuah. (2015). 'Analisis Penyerapan Tenaga Kerja Pada Sektor Usaha Kecil Dan Menengah (UMK) di Provinsi Jawa Tengah', Universitas Negeri Semarang Jurusan Ekonomi Pembangunan Fakultas Ekonomi.

Pirman, F. (2016). 'Pengaruh Upah dan Modal Terhadap Penyerapan Tenaga Kerja Pada Industri Kecil Menteng Kota Medan', Universitas Islam Negeri Sumatera Utara Fakultas Ekonomi dan Bisnis Islam.

Prabaningtyas, Y. M. (2015). 'Pengaruh Modal, Jumlah Unit Usaha, JumlahProduksi, Terhadap Penyerapan Tenaga kerjaIndustri Kecil Tahu Bakso Dengan Menggunakan Path Analisis', Universitas Negeri Semarang Jurusan Ekonomi Pembangunan Fakultas Ekonomi.

Safitri, D. (2017). 'Pengaruh Jumlah Unit Usaha Dan Tingkat Upah Terhadap Penyerapan Tenaga Kerja Sektor Industri Besar Dan Sedang Di Provinsi Lampung Periode 2001-2015 Dalam Perspektif Ekonomi Islam', Universitas Islam Negeri Raden Intan Lampung Fakultas

Sukarsono, M. N. (2019). 'Analisis Pengaruh Tingkat Upah, Modal, Pendapatan dan Jumlah Unit Usaha Terhadap Permintaan Tenaga Kerja Pada Usaha Kecil Menengah Bengkel Motor Di Wilayah Surabaya Selatan', Universitas Wijaya Kusuma Surabaya Program St.

Tri, D. U. (2016). 'Pengaruh Nilai Investasi, Jumlah Unit Usaha Dan Upah Minimum Terhadap Permintaan Tenaga Kerja Industri Kecil Dan Menengah Di Provinsi Jawa Tengah', Universitas Muhammadiyah Surakarta Program Studi Ekonomi Pembangunan Fakultas Ekonomi Da.

('Undang Undang No 5 Tahun 1984 Pasal 1 Ayat 2',)

('Undang Undang No 13 Tentang Ketenagakerjaan',)

Widyastuti, D. A. (2003). 'PengaruhJumlah Usaha, Nilai Investasi Dan Upah Minimum Terhadap Permintaan Tenaga Kerja Pada Industri Kecil Dan Menengah Di Provinsi Jawa Tengah Tahun 1997-2011', Universitas Diponegoro Semarang Fakultas Ekonomika Dan Bisnis. 